\title{
NOTE
}

\section{Aggregation Induced $\alpha$-Helix/ $\beta$-Sheet Transition of the Poly(ethylene glycol)-attached Peptide}

\author{
By Masayoshi TANAKA,${ }^{1}$ Souhei ABIKO, ${ }^{1}$ Tomoyuki KOGA, ${ }^{2}$ \\ Naokiyo KOSHIKAWA, ${ }^{3}$ and Takatoshi KINOSHITA,*
}

KEY WORDS: Peptides / Conjugated Polymer / Secondary Structural Transition / Self-assembly / Phase Separation /

Self-assembly of peptides is a promising tool for constructing nano-structural device, which shows emerging potential in material science. ${ }^{1-3}$ One of the most contributive features of peptides for these applications would be the transition ability of secondary structure such as $\alpha$-helix/random coil, random coil/ $\beta$-sheet, and $\alpha$-helix/ $\beta$-sheet transition. ${ }^{4-9}$ Especially, the $\beta$ sheet structure often provides unique self-assembled objects such as fibrils, ribbons, and barrels based on inter-strand hydrogen bonding. ${ }^{10-15}$

Amphiphilic block copolymer is another attractive building block for self-assembled nano-architecture. This kind of copolymer aggregates in aqueous media on the basis of phase separation between hydrophobic and hydrophilic segment. The constructed object forms a hydrophobic domain, which provides utilization as a container of chemical ingredients to be applied for drug delivery and controlled release system. ${ }^{16-18}$ In these systems, the formed hydrophobic domain shows aggregation and dissociation by the external stimuli. Thus, the designing of the stimuli-responsive component would directly influence the functions and the expression of unique selfassembling phenomenon.

We have focused on an amphiphilic copolymer constructed with a peptide as a hydrophobic and PEG as a hydrophilic segment. The peptide segment is composed of 16 residues, which contains a repetitive sequence of Leu-Glu-Leu-Leu (LELL) for four times (Figure 1a). The peptide would be assumed hydrophobic in virtue of abundant leucine residues (12 residues). The glutamic acid which was designed every four residues and $\mathrm{N}$-terminus amino group would contribute its $\mathrm{pH}$ responsiveness. Protonation and deprotonation of these moieties would influence on the solubility of the peptide segment. Since glutamic acid as a hydrophilic moiety located every four residues could be arranged on the same side, when the peptide segment of $\mathrm{H}_{2} \mathrm{~N}$-(LELL) $)_{4}$-PEG took a stretched conformation, i.e., $\beta$-sheet structure (Figure 1b). It is well known that peptide sequences constructed by alternative hydrophobic and hydrophilic amino acids tend to adopt $\beta$ sheet structure. ${ }^{19}$ The peptide segment, (LELL) $)_{4}$ having binary-

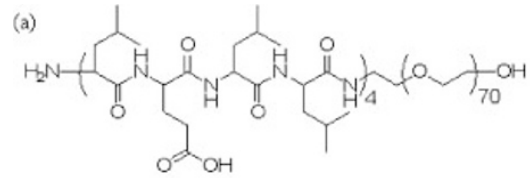

(b)

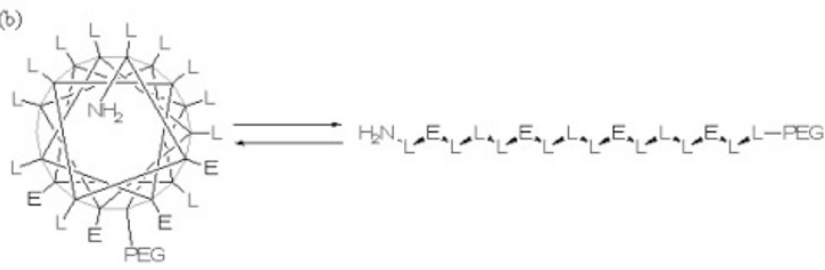

Figure 1. a) Structure of PEGylated peptide, b) Schematic illustration of the secondary structure of peptide-PEG block copolymer.

like sequence would adopt a stretched conformation as a stable conformation. In this report, secondary structural transition of PEGylated peptides cooperating with amphiphilicity and $\mathrm{pH}$ responsiveness of the peptide segment was investigated. We also describe a reversible $\alpha$-helix/ $\beta$-sheet transition of the peptide segment, which was controlled by the modulation of the charge balance in the peptide hydrophobic domain.

\section{EXPERIMENTAL}

\section{Materials}

The amphiphilic peptides were prepared by solid phase method using 9-fluorenylmethoxycarbonyl (Fmoc) strategy. The peptide chain was synthesized on a TentaGel PAP resin (RAPP Polymere), by using 3 equivalents of Fmoc-amino acid derivatives. The activation and coupling reactions have been conducted using 3 equivalent of 1-hydroxy-7-benzotriazole (HOAt), and 3 equivalent of 1,3-diisopropylcarbodiimide (DIPCDI) in $\mathrm{N}, \mathrm{N}$-dimethylformamide (DMF). And 20\% of piperidine was used in DMF for removal of Fmoc group. The $\mathrm{N}$-terminus of (LELL) $)_{4}$ was acetylated by 10 equivalent of acetic anhydride in DMF to give Ac-(LELL) ${ }_{4}$ on the resin. To

\footnotetext{
${ }^{1}$ Department of Frontier Materials, Graduate School of Engineering, Nagoya Institute of Technology, Gokiso-cho, Showa-ku, Nagoya 466-8555, Japan ${ }^{2}$ Department of Molecular Science \& Technology, Faculty of Engineering, Doshisha University, Kyotanabe, Kyoto 610-0321, Japan

3 Japan Aerospace Exploration Agency, 2-1-1 Sengen, Tsukuba 305-8505, Japan

*To whom correspondence should be addressed (Tel: +81-52-735-5267, Fax: +81-52-735-5267, E-mail: kinoshita.takatoshi@ nitech.ac.jp).
} 
cleave the peptides from the resin and deprotection of the side chain were carried out with trifluoroacetic acid (TFA)/1,2ethanedithiol/thioanisole/water (84:8:4:4). The peptides were precipitated and washed by diethylether.

Peptide having no PEG chain was prepared by same procedure with CLEAR-Amide resin (Peptide Institute. Inc.) instead of Tenta Gel PAP resin.

\section{Measurement}

The peptide dissolved in 2,2,2-trifluoroethanol(TFE) was diluted by milliQ water to be $2.6 \times 10^{-6} \mathrm{~mol} \mathrm{~L}^{-1}$ including $5 \%$ TFE. The $\mathrm{pH}$ of the solution was adjusted by the addition of $0.1 \mathrm{M} \mathrm{HCl}$ solution or $0.1 \mathrm{M} \mathrm{NaOH}$ solution. The secondary structure of peptide was investigated by circular dichroism (CD) spectroscopy. CD spectra were measured by J-820K spectropolarimeter (JASCO Ltd.) under a nitrogen atmosphere. Experiments were performed in a quartz cell with a $5 \mathrm{~mm}$ path length over the range of $190-260 \mathrm{~nm}$ at room temperature.

\section{Reversible Secondary Structure Transition}

$1 \mathrm{~mL}$ of aqueous solution of $\mathrm{H}_{2} \mathrm{~N}-(\mathrm{LELL})_{4}$-PEG $(2.6 \times$ $10^{-6} \mathrm{M}, \mathrm{pH} 3.0$ ) including $5 \%$ TFE was first prepared. The secondary structure of the peptide was monitored by $\mathrm{CD}$ spectroscopy for $6 \mathrm{~h}$. To adjust $\mathrm{pH}$ of the peptide solution, $1.3 \mu \mathrm{L}$ of sodium hydroxide $(6.0 \mathrm{M}, \mathrm{NaOH})$ was added to be $\mathrm{pH}$ 10.0. After monitoring the secondary structure for $24 \mathrm{~h}$, $1.3 \mu \mathrm{L}$ of hydrochloric acid $(6.0 \mathrm{M}, \mathrm{HCl})$ was injected into the peptide solution to be $\mathrm{pH}$ 3.0. Then, the secondary structure was monitored again by $\mathrm{CD}$ spectroscopy.

\section{RESULTS AND DISCUSSIONS}

The secondary structure of $\mathrm{H}_{2} \mathrm{~N}$-(LELL) $)_{4}$-PEG was investigated by $\mathrm{CD}$ spectroscopy (Figure 2A). At pH 3.0, the peptide showed negative peaks at 222 and $208 \mathrm{~nm}$, indicating existence of a right-handed $\alpha$-helix structure. It was suggested that peptide sequence enriched with leucine residues essentially forms $\alpha$-helix structure in aqueous solution. The CD spectra attributed to $\alpha$-helix structure have gradually changed into spectra with a single negative peak at $215 \mathrm{~nm}$, which was corresponded to typical $\beta$-sheet structure, suggesting that the peptide segment showed spontaneous $\alpha$-helix $/ \beta$-sheet transition in the aqueous media. As plotted in Figure 3a, the molar ellipticity differences at 208 and $215 \mathrm{~nm}\left([\theta]_{208} /[\theta]_{215}\right)$ as a ratio of $\alpha$-helix $/ \beta$-sheet content decreased gradually. The transition from $\alpha$-helix to $\beta$-sheet was completed within $4 \mathrm{~h}$. Peptide moiety having no PEG chain; $\mathrm{H}_{2} \mathrm{~N}$-(LELL) $)_{4}$ was separately prepared and the secondary structure in aqueous solvent at $\mathrm{pH} 3.0$ was monitored by CD spectrum. It showed stable $\alpha$-helix even after incubating for $24 \mathrm{~h}$ (Figure $3 \mathrm{~b}$ ). It was suggested that PEG chain plays a decisive role to show the spontaneous secondary structural transition. On the other hand, the peptide segment of the PEGylated peptide showed $\alpha$-helix structure at $\mathrm{pH}$ 10.0, where glutamic acid was deprotonated to be highly hydrophilic moiety (Figure $2 \mathrm{~B}$ ). The value of
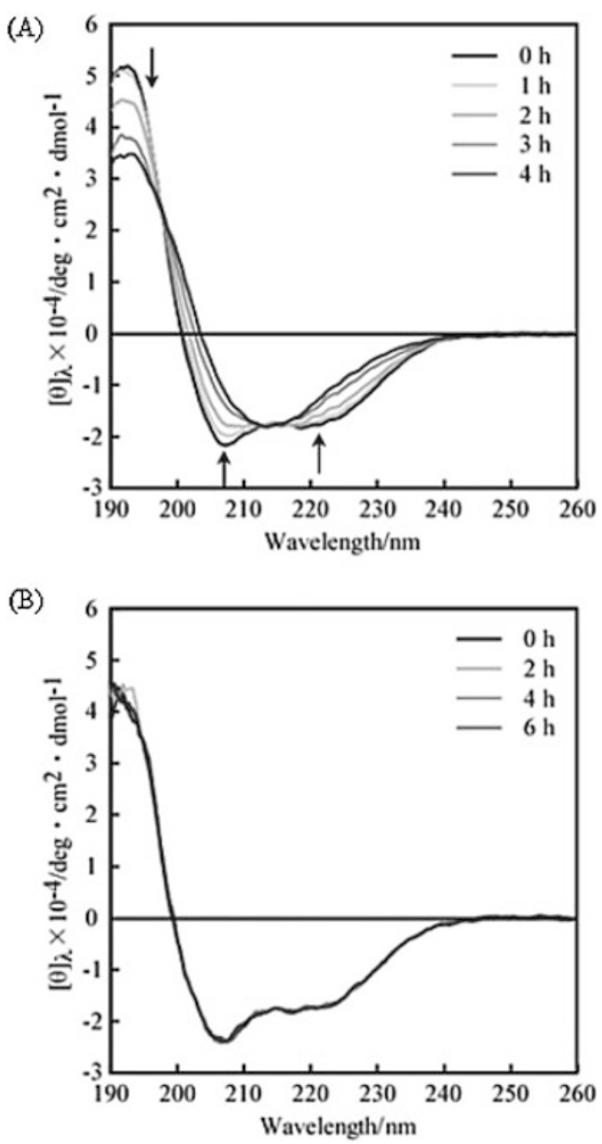

Figure 2. Changes in $\mathrm{CD}$ spectra for $\mathrm{H}_{2} \mathrm{~N}-(\mathrm{LELL})_{4}-\mathrm{PEG}$ at $(\mathrm{A}) \mathrm{pH} 3.0$, and (B) $\mathrm{pH}$ 10.0. $\left[\mathrm{PEG}\right.$ ylated peptide] $=2.6 \times 10^{-6} \mathrm{~mol} / \mathrm{L}$.

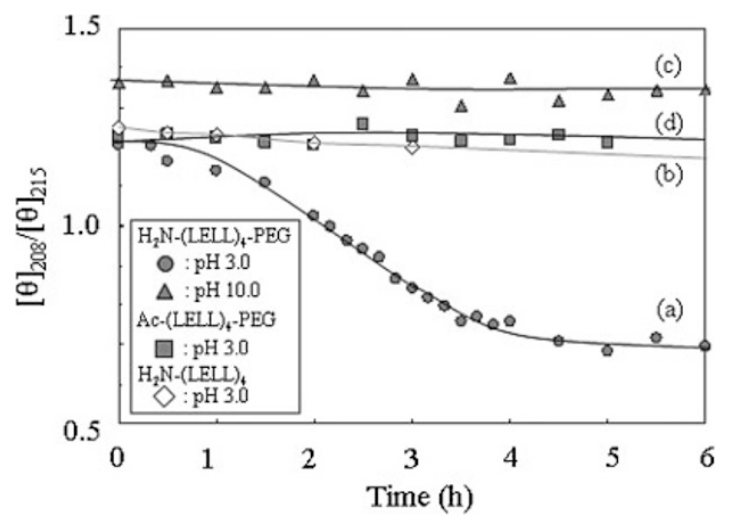

Figure 3. Time dependency of $[\boldsymbol{\theta}]_{208} /[\boldsymbol{\theta}]_{215}$ for (a) $\mathrm{H}_{2} \mathrm{~N}$-(LELL) $)_{4}-\mathrm{PEG}$, (b) $\mathrm{H}_{2} \mathrm{~N}-(\mathrm{LELL})_{4}$ at $\mathrm{pH} 3.0$, (c) $\mathrm{H}_{2} \mathrm{~N}-(\mathrm{LELL})_{4}-\mathrm{PEG}$ at $\mathrm{pH} 10.0$ and (d) Ac-(LELL) $)_{4}-\mathrm{PEG}$ at $\mathrm{pH} 3.0$.

$[\theta]_{208} /[\theta]_{215}$ showed little change even after $24 \mathrm{~h}$, indicating that $\alpha$-helix structure was stable at $\mathrm{pH} 10.0$ (Figure 3c). The observed transition of secondary structure was also influenced by $N$-terminus structure of the peptide segment. The acetylated moiety at $N$-terminus amino group of the peptide segment, Ac-(LELL) ${ }_{4}$-PEG, showed a stable $\alpha$-helix at $\mathrm{pH} 3.0$ as plotted in Figure 3d. From these results, it was indicated that the 
Table I. The CAC values of the peptide-PEG

\begin{tabular}{ccrc}
\hline & Peptide-PEG & $\mathrm{pH}$ & $\mathrm{CAC} / \mathrm{mol} / \mathrm{L}$ \\
\hline 1 & $\mathrm{H}_{2} \mathrm{~N}(\mathrm{LELL})_{4}$-PEG & 3.0 & $4.2 \times 10^{-7}$ \\
2 & & 10.0 & n.d. \\
3 & $\mathrm{Ac}(\mathrm{LELL})_{4}-\mathrm{PEG}$ & 3.0 & $3.6 \times 10^{-7}$ \\
\hline
\end{tabular}

The CAC was estimated from the $\lambda_{1} / \lambda_{3}$ value of pyrene fluorescence spectrum. [pyrene] $=6.1 \times 10^{-7} \mathrm{M}, \lambda_{\mathrm{ex}}=335 \mathrm{~nm}$

observed $\alpha$-helix $/ \beta$-sheet transition of $\mathrm{H}_{2} \mathrm{~N}$-(LELL) $)_{4}$-PEG at $\mathrm{pH} 3.0$ was governed either by the charge state of $N$-terminus group and side chain of the peptide segment.

We presumed that the observed transition was deeply involved in aggregation based on the amphiphilicity of the PEGylated peptides. Critical aggregation concentration (CAC) of the PEGylated peptides in the aqueous solution including TFE (5\%) was estimated by means of the $\lambda_{1} / \lambda_{3}$ value of the pyrene fluorescence spectrum (Table I). $\mathrm{H}_{2} \mathrm{~N}$-(LELL) $)_{4}$-PEG showed no $\mathrm{CAC}$ at $\mathrm{pH} 10.0$, indicating that the PEGylated peptide dispersed well in the solution. The peptide segment enriched hydrophilicity, since glutamic acid deprotonated at the alkaline condition to be anionic moiety. Thus, as a dispersed state, the peptide segment adopts $\alpha$-helical structure, according to the essential nature of the peptide segment enriched with leucine residues. On the other hand, $\mathrm{H}_{2} \mathrm{~N}$ (LELL) $)_{4}$-PEG and Ac-(LELL) 4 -PEG showed CAC at $\mathrm{pH} 3.0$, indicating that the peptide-PEG moieties aggregate to give hydrophobic domains in the solutions. At the acidic condition, where glutamic acid residues were protonated, hydrophobicity of the peptide segment was relatively high. The phase separation between PEG and peptide would be contributive to form hydrophobic domain in the solution. Since the concentrations of PEGylated peptide solutions in the $\mathrm{CD}$ measurement $\left(2.6 \times 10^{-6} \mathrm{~mol} \mathrm{~L}^{-1}\right)$ were higher than the estimated CACs, the PEGylated peptides would adopt micelle-like structure. By casting a drop of each PEGylated peptide solution at $\mathrm{pH} 3.0$ on mica, the aggregate was observed by atomic force microscope (AFM) after drying the substrate. Grain-like aggregates were observed as shown in Figure $4 \mathrm{a}$ and c for $\mathrm{H}_{2} \mathrm{~N}$-(LELL) $)_{4}$-PEG and Ac-(LELL) $)_{4}-\mathrm{PEG}$, respectively. These results support that the PEGylated peptides formed hydrophobic domain to give micelle-like structure.

$\mathrm{H}_{2} \mathrm{~N}$-(LELL) $)_{4}$-PEG which showed $\alpha$-helix $/ \beta$-sheet transition within $4 \mathrm{~h}$ at $\mathrm{pH} 3.0$, showed morphological transition. The grain-like aggregates transformed into fibrous object (Figure $4 \mathrm{~b}$ ). The width of the observed fiber was estimated to be $6 \mathrm{~nm}$, which was agreed with the length of the $\beta$-strand with 16 residues. On the other hand, Ac-(LELL) 4 -PEG showed no morphological transition after $4 \mathrm{~h}$ (Figure $4 \mathrm{~d}$ ). These results of morphological transition accorded with the CD measurements. $\mathrm{N}$-terminus of $\mathrm{H}_{2} \mathrm{~N}$-(LELL) - $_{4}$-PEG is protonated to be cationic moiety at $\mathrm{pH} 3.0$. These cationic moieties cause charge repulsion in the formed hydrophobic domain. This repulsive force in the hydrophobic domain would trigger the secondary structural transition. $N$-terminus of Ac-(LELL) 4 -PEG having no charge, is no longer perturbunt of the hydrophobic domain,

\section{$\mathrm{H}_{2} \mathrm{~N}-(\mathrm{LELL})_{4}-\mathrm{PEG}$}
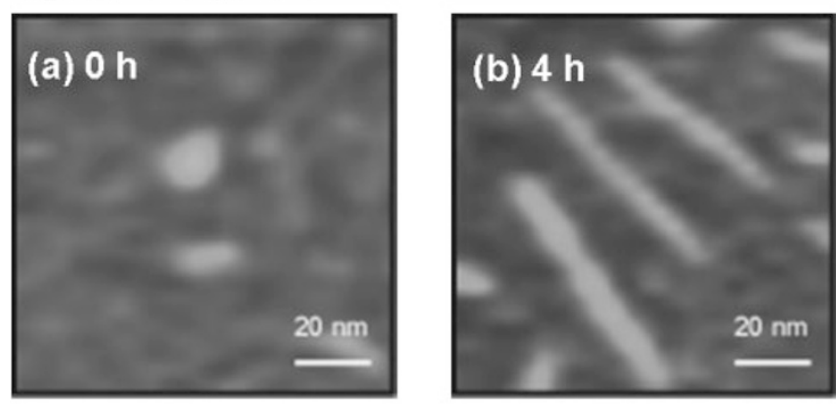

\section{Ac-(LELL) $)_{4}$-PEG}
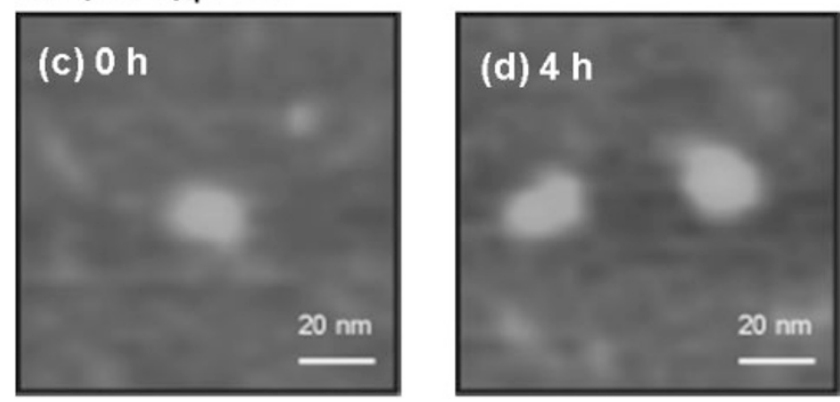

Figure 4. $A F M$ images of aggregates obtained by casting a drop of fresh $\mathrm{H}_{2} \mathrm{~N}$-(LELL) ${ }_{4}-\mathrm{PEG}$ solution (a), after 4 hours (b), Ac-(LELL) $)_{4}-\mathrm{PEG}$ solution (c), and after $4 \mathrm{~h}(\mathrm{~d})$.

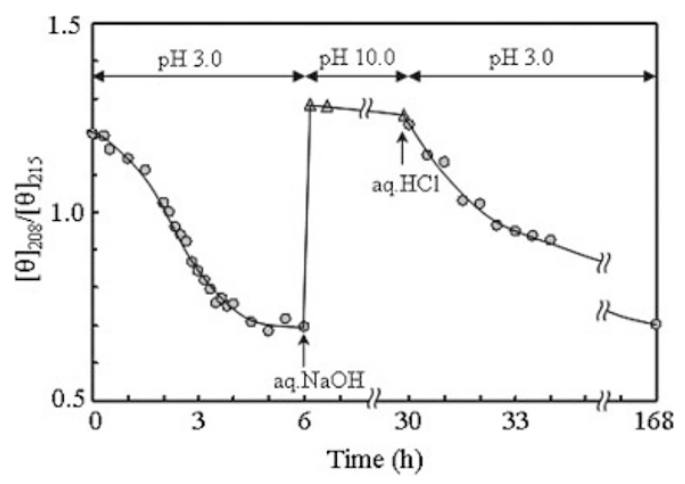

Figure 5. Time dependency of $[\boldsymbol{\theta}]_{208} /[\boldsymbol{\theta}]_{215}$ for $\mathrm{H}_{2} \mathrm{~N}-(\mathrm{LELL})_{4}-\mathrm{PEG}$ at $\mathrm{pH} 3.0$. The arrows indicate at which $\mathrm{pH}$ was adjusted by adding aqueous $\mathrm{NaOH}$ and aqueous $\mathrm{HCl}$ in the solution.

because there is no repulsive force due to the protecting of $N$ terminus amino group. Thus, the micelle-like aggregation of Ac-(LELL) 4 -PEG derived from amphiphilicity was kept without the further secondary structural transition of the peptide segment. It was suggested that aggregation according to the balance of amphiphilicity and stability of the formed hydrophobic domain would be dominant factors for the observed $\alpha$ helix / $\beta$-sheet transition.

The CD spectra have revealed that the observed secondary structural transition was reversibly proceeded by adjusting $\mathrm{pH}$ of the peptide solution (Figure 5). The spectra observed at $\mathrm{pH} 3.0$ having a negative peak at $217 \mathrm{~nm}$ had quickly changed 
into spectra having negative peaks at 222 and $208 \mathrm{~nm}$, when $\mathrm{pH}$ was adjusted at 10.0 by adding $\mathrm{NaOH}$ aqueous solution, suggesting that the $\beta$-sheet structure of peptide segment transformed into $\alpha$-helix immediately. The $\alpha$-helix structure was stable at $\mathrm{pH} 10.0$ at least for $24 \mathrm{~h}$. Reversibility of the secondary structure of the peptide segment was simply controlled by $\mathrm{pH}$ adjustment. When the $\mathrm{pH}$ was re-adjusted to $\mathrm{pH} 3.0$ by adding $\mathrm{HCl}$ aqueous solution, $\alpha$-helix was gradually transformed into $\beta$-sheet again. The second transition from $\alpha$-helix to $\beta$-sheet took several days to complete the transition, which was slower than the first transition. It could be attributed to the effect of the formed sodium chloride. Since the adjustment of $\mathrm{pH}$ was carried out by successive addition of $\mathrm{HCl}$ and $\mathrm{NaOH}$, sodium chloride was formed in the solution. Since the formed salts would weaken the repulsive force between cationic moieties at $N$-terminus of $\mathrm{H}_{2} \mathrm{~N}$-(LELL) $)_{4}$-PEG, the second $\alpha$-helix $/ \beta$-sheet transition took much time.

In summary, we have synthesized PEGylated peptide with pH-responsive peptide sequence, which showed reversible $\alpha$ helix / $\beta$-sheet transition. These transitions have been dominated by hierarchical phase separation process, that is, the process based on aggregation derived from amphiphilicity of the PEGylated peptide, and the following process based on relief from the repulsive force in the formed hydrophobic domain. The observed secondary structural transition was readily controlled by $\mathrm{pH}$ change. Such unique reversible transition of the secondary structure will provide a novel strategy for construction of the intelligent and programmed nano-architectures.

Acknowledgment. A part of this work was performed as the "International space station applied research partnership program" of the Japan Aerospace Exploration Agency (JAXA) and the Nagoya Institute of Technology.
Received: August 11, 2008

Accepted: October 21, 2008

Published: December 5, 2008

\section{REFERENCES}

1. H. A. Behanna, K. Rajangam, and S. I. Stupp, J. Am. Chem. Soc., 129, 321 (2007)

2. I. W. Hamley, I. A. Ansari, V. Castelletto, H. Nuhn, A. Rösler, and H.-A. Klok, Biomacromolecules, 6, 1310 (2005).

3. J. Kisiday, M. Jin, B. Kurz, H. Hung, S. Zhang, and A. J. Grodzinsky, Proc. Natl. Acad. Sci. U.S.A., 99, 9996 (2002).

4. R. Mimna, M.-S. Camus, A. Schmid, G. Tuchscherer, H. A. Lashuel, and M. Mutter, Angew. Chem., Int. Ed., 46, 2681 (2007).

5. T. Koga, K. Taguchi, Y. Kobuke, T. Kinoshita, and M. Higuchi, Chem. Eur. J., 9, 1146 (2003).

6. T. Koga, M. Matsuoka, and N. Higashi, J. Am. Chem. Soc., 127, 17596 (2005).

7. E. Kauffmann, N. C. Darnton, R. H. Austin, C. Batt, and K. Gerwert, Proc. Natl. Acad. Sci. U.S.A., 98, 6646 (2001).

8. J. Jarvet, P. Damberg, K. Bodell, L. E. G. Eriksson, and A. Gra1slund, J. Am. Chem. Soc., 122, 4261 (2000).

9. S. Zhang and S. A. Rich, Proc. Natl. Acad. Sci. U.S.A., 94, 23 (1997).

10. H. Yokoi, T. Kinoshita, and S. Zhang, Proc. Natl. Acad. Sci. U.S.A., 102, 8414 (2005).

11. M. Tanaka, M. Hattori, and T. Kinoshita, Chem. Lett., 36, 562 (2007).

12. A. Brizard, R. Kiagus, and R. Oda, Chem. Commun., 2275 (2007).

13. K. Lu, L. Guo, A. K. Mehta, W. S. Childers, S. N. Dublin, S. Skanthakumar, V. P. Conticello, P. Thiyagarajan, R. P. Apkarian, and D. G. Lynn, Chem. Commun., 2729 (2007).

14. J. M. Rausch, J. R. Marks, and W. C. Wimley, Proc. Natl. Acad. Sci. U.S.A., 102, 10511 (2005).

15. T. Beke, A. Czajlik, B. Bálint, and A. Perczel, ACS Nano, 2, 545 (2008).

16. Y. Lee, S. Fukushima, Y. Bae, S. Hiki, T. Ishii, and K. Kataoka, J. Am. Chem. Soc., 129, 5362 (2007).

17. G. Gao, T. Wang, J. He, X. Chen, and Y. Yang, Macromolecules, 40 2613 (2007).

18. R. Sigel, M. Łosik, and M. Schlaad, Langmuir, 23, 7196 (2007).

19. W. F. DeGrado and J. D. Lear, J. Am. Chem. Soc., 107, 7684 (1985). 